\title{
PSYCHE
}

VOL. XXXV.

SEPTEMBER 1928

No. 3

\section{NEW PLASTOCERIDE AND A NEW CEBRIO (COLEOPTERA)}

\author{
By H. C. FALL,
}

Tyngsboro, Mass.

The little family of aberrant Elaterids known as the Plastoceridæ contains thus far only twenty described species from within our faunal limits, and these are very sparingly represented in the great majority of collections. The wingless females especially are very rarely taken, and in a series of one hundred of more individuals in my own cabinet only three are of this sex.

With the exception of Euthysanius blaisdelli Tanner, described two years ago, ${ }^{1}$ no new species of this genus or of Aplastus has been made known in over half a century. Descriptions or five new forms in these genera, and of a new Aphricus are offered in the following pages. The types of all these are in my own collection.

\section{Euthysanius horni n. sp.}

Body above, legs and antennæ pale reddish brown, metasternum and abdomen more flavate; integuments shining, pubescence very short, pale and suberect.

Antennæ of male flabellate as usual, the terminal joint perceptibly though only slightly shorter than the branch of the 11th joint. Head densely punctate, a transverse impression between the eyes which is posteriorly angulate at middle; eyes prominent, separated on the front by a little more than twice their width as viewed from the front.

'Pan Pacific Entomologist, April, 1926, p. 188. 
Prothorax nearly trapezoidal, length along the median line about one-tenth greater than its width at middle; sides almost perfectly straight, only just perceptibly flaring at the hind angles, the width across the tips of the latter two-fifths greater than the apical width; surface evenly convex with only the faintest trace of the antemedian impressions so conspicuous in lautus; punctuation fine and not dense, the punctures separated on the average by about their own diameters.

Elytra slightly more than three times as long as wide, and one-fourth wider than the thorax across the tips of the hind angles; striæ barely visibly impressed except toward the sides and apex, the intervals nearly flat and with fine punctures which are not much larger than those of the striæ.

Propleura finely not densely punctate, becoming smoother internally; metasternum and abdomen more closely punctate. Legs slender, tibiæ straight, outer margin not sinuate.

Length $17 \mathrm{~mm}$; ; width $4.2 \mathrm{~mm}$.

Described from a single male specimen taken at Olancha, Owens Valley, California, June 19, 1917 by G. R. Pilate.

Smaller, a little narrower, and paler in color than lautus, the disparity between the lengths of the terminal joint of the antennæ and of the branch of the preceding joint less marked, the prothorax more elongate with straighter sides and less divergent hind angles, much sparser punctuation, more obtuse lateral margins, and less impressed elytral striæ. Furthermore in lautus the propleura are densely punctate and the middle tibiæ (especially) are distinctly sinuate; not so in the present species. Horni agrees more nearly in size with pretiosus but the latter has a very much stouter thorax, the width across the tips of the strongly flaring hind angles subequal to the width of the elytra at base, and the punctuation much sparser.

I am very much inclined to believe that the species here described is that figured by Horn (Trans. American Ent. Soc. vol. IX, Pl. I, fig. 2) and alluded to by him in the accompanying text as a possible variety of lautus. The relatively longer terminal antennal joint and non-sinuate middle tibiæ as compared with the figure of lautus on the same plate are in agreement with 
the present species, though here the sides of the thorax are straighter and hind angles less divergent than in the figure.

Notwithstanding Horn's statement that in lautus the thorax is "always longer than wide at middle" it is not so in any of my dozen specimens, nor is it true of either of the two examples in the LeConte collection, in both of which the length at middle is approximately one-seventh less than the median width.

\section{Euthysanius imparoculatus n. sp.}

Smaller than the other known species of the genus; rufotestaceous, beneath a little paler, thorax moderately shining, elytra duller. Terminal antennal joint very distinctly shorter than the branch of the preceding. Head coarsely densely punctate; leyes much less convex and less prominent than usual, separated across the front by four times their own width.

Prothorax subcampanulate, very nearly as long as the width across the middle; sides rounded in front, straight and parallel in the middle third, the hind angles strongly divergent; surface rather finely not closely punctate, the punctures separated by from one to two times their own diameters.

Elytra at base slightly wider than the distance across the base angles of the thorax; sides parallel in basal two-thirds; striæ feebly impressed, punctuation about as usual. Propleura sparsely finely punctate, polished. Tibiæ not sinuate.

Length $15.5 \mathrm{~mm}$.; width $4 \mathrm{~mm}$.

White Mts., Gila Co., Arizona, July 1-15, 1925 (Poling). A single male.

This is a very distinct species, separable at once from all others known by its coarsely punctate head and non-prominent eyes. In the present species and also in lautus the scutellum is minutely notched at tip; there is scarcely a trace of this notch in either pretiosus or horni.

\section{Aplastus scabripennis n. sp.}

Elongate, parallel, brown, head and elytra dull, thorax shining, pubescence grayish moderately conspicuous. 
Head densely rather coarsely punctate, antennæ long, strongly serrate, the 8 th joint attaining the tip of the hind angle of the thorax; joints 2-3 small, subequal, together two-thirds as long as the 4 th.

Prothorax slightly wider at middle than its median length, sides straight and moderately diverging to the hind angles which are more strongly divergent and carinate; disk convex, median line feebly impressed, punctuation somewhat finer than on the head, rather sparse at middle, the punctures there separated by from one to two times their diameters, closer toward the margins. The sides are evidently though feebly margined.

Elytra nearly parallel sided, three times as long as wide, very feebly obsoletely striate, intervals densely scabrous punctate.

Last ventral segment one-half longer than the preceding, feebly sinuate each side of the apex which is narrowly subtruncate. Middle and hind tarsi distinctly longer than the tibiæ.

Length $16 \mathrm{~mm}$; width $3.9 \mathrm{~mm}$.

California (Camp Nelson, Tulare Co., Aug. 28, 1913); a single male example.

By Horn's table this species is to be associated with optatus, from which it differs by the almost obsolete elytral striæ and the densely scabrous punctate and dull interspaces. In optatus the 3rd antennal joint though small is plainly longer and wider than the 4th; only very slightly so in the present species.

\section{Aplastus piceicollis n. sp.}

Form slender, head and pronotum piceous, elytra ferruginous brown, strongly shining throughout, the pubescence sparse and very fine.

Head closely strongly punctate; antennæ strongly serrate, 8th joint reaching tip of hind angle of thorax, 2nd joint very small, transverse, 3rd subtriangular, very nearly twice as long as the 2nd and distinctly longer than wide, the two together about two-thirds the length of the 4 th joint.

Prothorax about one-seventh longer on the median line than the median width; sides straight, barely visibly diverging to the flaring hind angles which are strongly produced and finely 
carinate; front margin briefly sinuato-truncate at middle, thence straight and oblique to the front angles; disk finely sparsely punctate, median line obsoletely impressed; sides finely margined.

Elytra three and one-half times as long as wide, very slightly attenuate posteriorly, finely striate, intervals finely not densely punctate and shining.

Prosternum longitudinally obtusely carinate in posterior half. Last ventral segment barely visibly sinuate each side of a narrow apical truncation; legs slender, tarsi slightly longer than the tibiæ.

Length $15.5 \mathrm{~mm}$; width $3.5 \mathrm{~mm}$.

California (Monache Meadows, Tulare Co., 8000-8300 ft., July 15-18, 1913); a single male collected by G. R. Pilate.

Allied to optatus by the margined sides of the prothorax but more slender, with longer 3rd antennal joint, and with the prothorax distinctly longer than wide. The dark color of the head and thorax may or may not prove constant and the same may be said of the prosternal carination.

\section{Aplastus productus n. sp.}

Moderately elongate, distinctly attenuate posteriorly, brownish ferruginous, moderately shining, finely pubescent.

Head closely rather coarsely punctate; antennæ moderately strongly serrate, 8th joint reaching the hind angle of the thorax, 2nd and 3rd joints very nearly equal, each wider than long, together about two-thirds as long as the 4th.

Prothorax about nine-tenths as long on the median line as the median width, sides nearly straight and moderately divergent, the hind angles relatively short and only slightly more diverging than the sides; punctuation fine, nearly evenly dispersed, the punctures separated by about twice their diameters as a rule; disk rather strongly evenly convex, sides finely margined.

Elytra not quite three times as long as wide, distinctly attenuate from the humeri, sides nearly straight as far as the apical 
fourth, striæ fine but distinctly impressed, intervals moderately punctate.

Prosternum not at all carinate; last ventral deeply sinuate each side of the apex which is produced to form a subtrapezoidal lobe nearly as long as wide and having its apex distinctly emarginate; middle and hind tarsi noticeably longer than the tibiæ.

Length $14.5 \mathrm{~mm}$; width $3.8 \mathrm{~mm}$.

California. A single male from Fresno Co.

This species like the two preceding falls near optatus by Horn's table, but it differs conspicuously from all of these by the short hind angles of the thorax and the remarkable apical ventral process.

\section{Aphricus tenuis n. sp.}

Very elongate, parallel, dark fuscous brown, moderately shining, pubescence fine, short, grayish and not dense.

Antennæ long, filiform, attaining the apical third of the elytra, joints 2-3 small, the latter slightly longer, together about two-thirds as long as the 4th; 4-11 very gradually increasing in length and diminishing in width, nearly parallel sided, the 4th about two and one-half times as long as wide, the 11th about seven times as long as wide and two-thirds longer than the 4th. Front feebly concave, margin acute, narrow and only slightly reflexed, oblique at sides, subtruncate at middle, rather finely and not closely punctate; eyes moderate.

Prothorax scarcely wider than the head, one-fourth longer than wide, sides straight and parallel almost throughout, a little incurved at apex and with moderately divergent hind angles which are very finely feebly carinate; side margins fine and entire, gradually obliquely descending toward the front; surface very finely sparsely evenly punctate, integuments polished.

Elytra elongate, parallel, a little more than three times as long as wide, three and one-third times as long and not quite one-fourth wider than the thorax; punctate striate, the striæ scarcely impressed except slightly so at base, intervals sparsely finely punctate.

Prosternum and propleura finely sparsely punctate, meta- 
sternum and ventral segments more closely punctured, the terminal segment especially more densely so. The terminal segment is obliquely subsinuately narrowed through the greater part of its length, paler in color at apex which is narrowly subtruncate and clothed with more yellowish pubescence; it has a submarginal impression each side near the base.

Length 6-8.2 mm.; width 1.4-1.75 mm.

Described from a series of seven specimens taken in the Pinal Mts., Arizona, 5000 ft. (O. C. Poling collector).

There are no obvious secondary sexual characters in the series at hand, but one example, from the exposed genitalia is certainly a male, and it is highly probable that all are of this sex.

I am by no means entirely satisfied as to the propriety of referring this species to Aphricus, from the type (A. californicus) of which it differs in the following respects. Tarsal joints 1-4 decrease rapidly in length, the basal joint subequal to 2 and 3 united and joint 2 subequal to 3 and 4 united; in Aphricus joints 1 and 2 are subequal while 3 and 4 are only slightly shorter. In the present species the side margins of the thorax are distinct and entire, in Aphricus they are in great part obliterated. In the present species the middle coxæ are very narrowly separated and the metasternal process between them is very acute; in typical Aphricus the middle coxæ are more widely separated, the metasternal process wider and obtuse at tip. In this connection it should be remarked that the side margins of the prothorax may be either present or absent in Aplastus and that while A phricus luteipennis agrees with californicus in tarsal structure and non-margined thorax, it has the more approximate middle coxæ and acute metasternal process of the present species. The mandibles in the present species are acute at tip nearly as in californicus, but with the tooth of the inner margin less remote from the tip. The prosternal lobe is extremely short and obtusely rounded, the prosternal sutures nearly straight, single, and not excavate in front, the coxal plates scarcely toothed at the insertion of the thighs, and the sixth ventral segment not visible, all as in A. californicus. 


\section{Cebrio speratus n. sp.}

Moderately elongate, parallel, dark brown and somewhat shining above; antennæ, legs and body beneath rufo-to fulvotestaceous. Head densely strongly punctate, labrum broadly angulate emarginate. Antennæ moderately serriform, passing the hind angles of the thorax by about four joints, 3rd joint slightly more than half as long as the 4 th, median joints scarcely one-half longer than wide.

Prothorax at middle about one-fifth wider than the median length, sides feebly arcuate to nearly straight, converging slightly toward the front, lightly sinuate before the hind angles which are small and strongly divergent; surface rather finely punctate, the punctures distant on the average by their own diameters or a little more.

Elytra nearly parallel sided, four and one-half times as long and one-third wider than the thorax; striæ rather feebly impressed, the strial punctures not or with difficulty distinguishable from those of the closely punctate intervals.

Prosternal intercoxal process narrow or sublinear, last ventral segment evenly rounded at apex.

Length 12.5 to $14.5 \mathrm{~mm}$; width 3.6 to $4.2 \mathrm{~mm}$.

Described from a series of twelve specimens from Hope, Arkansas (June 18-July, Miss Louis Knobel) and Winnfield, Louisiana (June 15, G. R. Pilate). The type is from the first named locality; all examples are males.

This species is allied to both bicolor and antennatus. From the former it differs in being generally smaller, with more finely and less closely punctured thorax, more feebly impressed elytral striæ, narrower prosternal process and unemarginate last ventral. Concerning a specimen sent to Mr. Schaeffer for comparison with his type of antennatus, he writes- "Differs from antennatus in being less elongate, the punctuation of the thorax finer and less close, the hind angles more strongly divaricate, the antennæ shorter with the joints less strongly produced apically." 

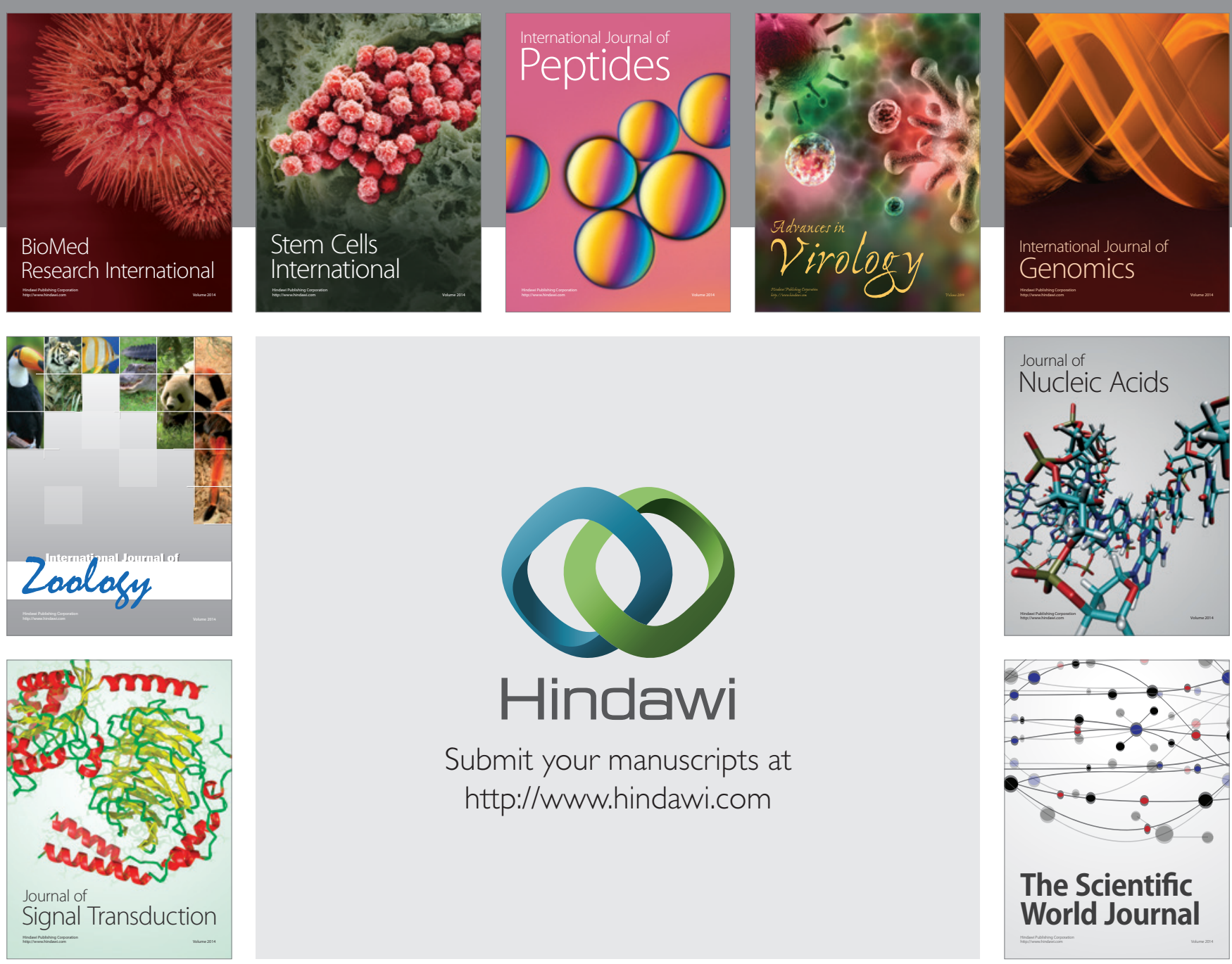

Submit your manuscripts at

http://www.hindawi.com
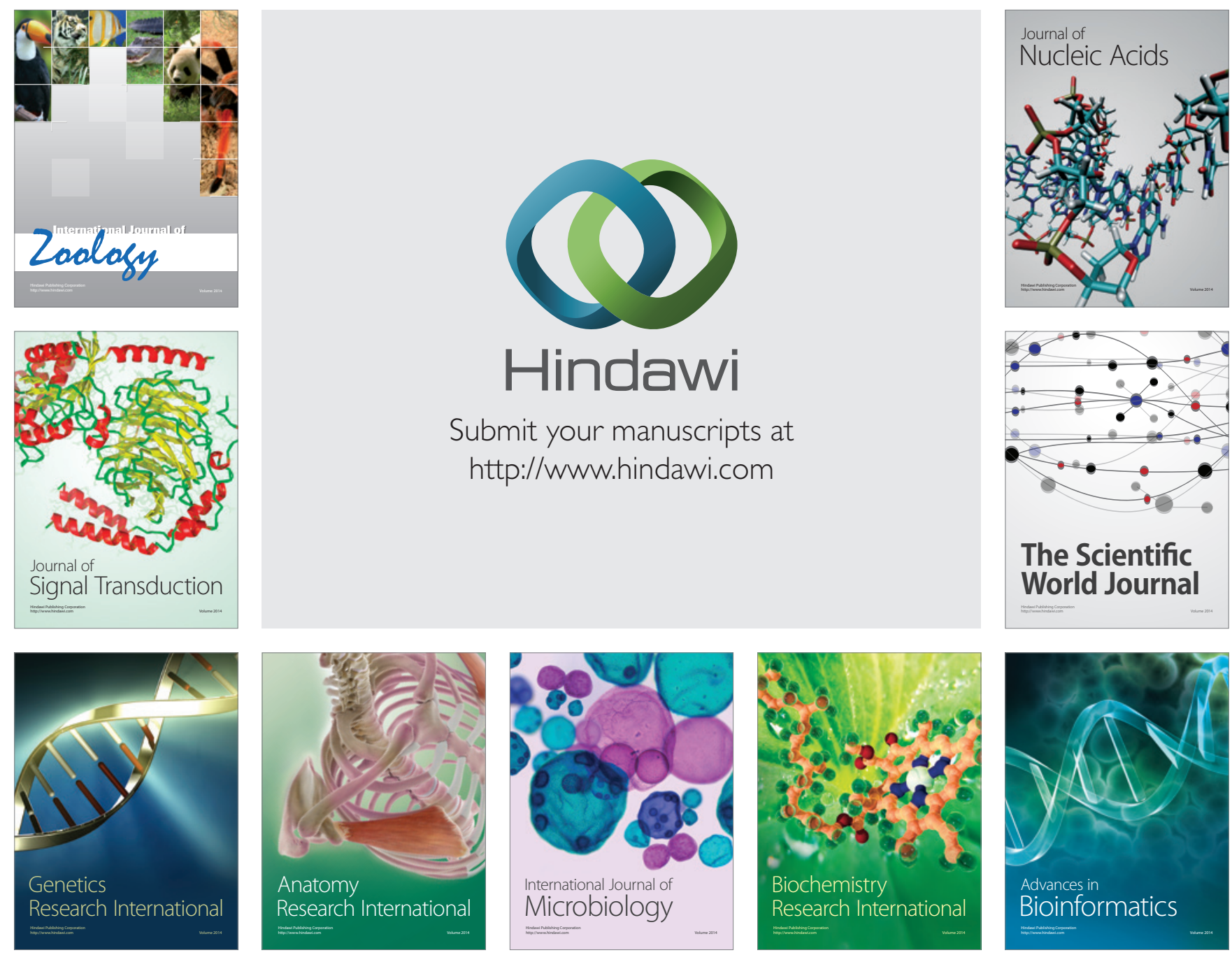

The Scientific World Journal
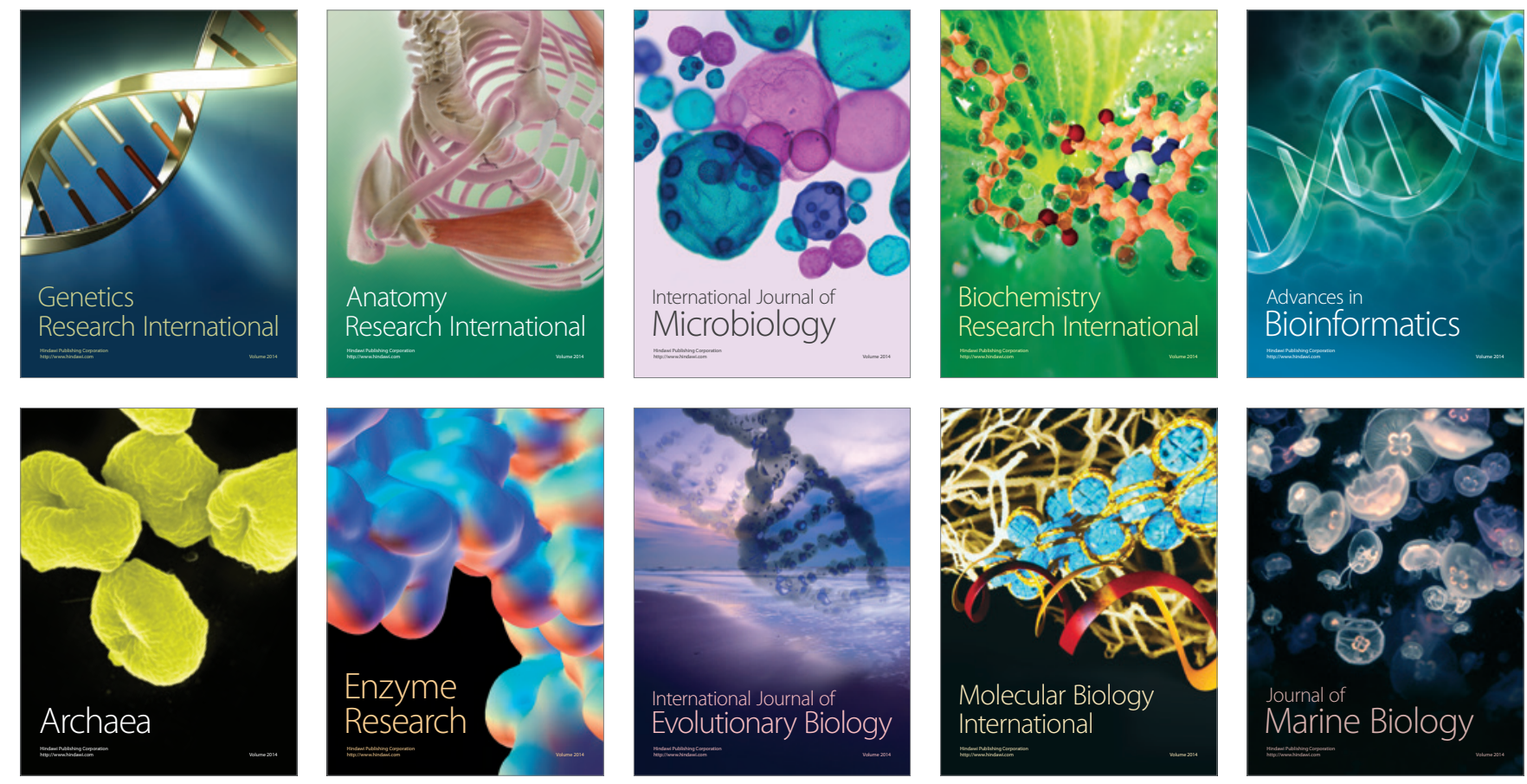